\title{
Persistent Organic Pollutants (POPs): A Primer for Practicing Clinicians
}

\author{
Darrah Haffner • Arnold Schecter
}

Published online: 15 March 2014

(C) Springer International Publishing AG 2014

\begin{abstract}
Persistent organic pollutants (POPs) are environmental chemicals that persist in the environment for long periods of time. The UN, under the Stockholm Convention, has regulated many of these POPs. However, because of their long half-lives, human exposure persists for decades even after production has been stopped. The health effects are varied and range from skin rashes to developmental delays to cancer, depending on the level of exposure. This review is meant as a primer for practicing clinicians to help identify acute exposure, to provide guidance to questioning patients, and be well-informed with regards to policy changes. It touches upon human exposure, current regulations, and health effect of the persistent organic pollutants, including: dioxin, polychlorinated biphenyls (PCBs), polybrominated diphenyl ethers (PBDEs), hexabromocyclododecane (HBCD), and the endocrine disruptor bisphenol A (BPA).
\end{abstract}

Keywords Persistent organic pollutants · POPs · Dioxin · Polychlorinated biphenyl ethers $\cdot$ PCBs $\cdot$ Polybrominated diphenyl ethers $\cdot$ PBDEs $\cdot$ Hexabromocyclododecane HBCD · Bisphenol A · BPA · Stockholm Convention

\section{Introduction}

Persistent organic pollutants (POPs) are well known environmental pollutants, of which the most well-known are dioxins,

D. Haffner $(\bowtie)$

Children's Medical Center, 1935 Medical District Dr, Dallas, TX 75235, USA

e-mail: Darrah.haffner@childrens.com

\section{A. Schecter}

University of Texas School of Public Health, Dallas Regional Campus, 6011 Harry Hines Blvd, Suite V8.112, Dallas, TX 75390, USA

e-mail: Arnold.schecter@utsouthwestern.edu polychlorinated biphenyls (PCBs) and polybrominated diphenyl ethers (PBDEs). Throughout recent history there have been multiple incidents where POPs have made it to the mainstream media. In 1962, Rachel Carson published Silent Spring about dichlorodiphenyltrichloroethane (DDT) and its impact on the environment, especially bird populations. Carson publicized that birds who ate DDT laid thinner shelled eggs, leading to their premature cracking/hatching and thus death $[1,2]$. Her book ultimately led to the banning of DDTs in 1972. In 1968, over 1000 people ate PCB-contaminated rice oil in Yusho, Japan; PCB contaminated rice oil affected over 1000 people in the western part of Japan [3]; a similar incident occurred just over ten years later in Yucheng, Taiwan in 1979. Affected people showed pigmentation of their nails, acneiform eruptions, conjunctivitis, numbness and weakness [4]. More recently, in 2004, Ukrainian President Viktor Yushchenko was poisoned by 2, 3, 7, 8tetrachlorodibenzo-p-dioxin (TCDD) [5].

The Stockholm Convention, which controls many of these chemicals at a global level, is a treaty ratified by the global convention, organized by the United Nations Environment Program (UNEP). It was initially created in 2001 and signed in 2004 to eliminate, restrict or reduce the purposeful and unintentional production of the "dirty dozen," a group of persistent organic pollutants identified in 2001. The dirty dozen included aldrin, dieldrin, chlordane, DDT, endrin, heptachlor, mirex, toxaphene, PCBs, hexachlorobenzene (HCB), dibenzodioxins, and dibenzofurans [6]. Since then 11 new chemicals have been added. See Table 1 for a listing of all persistent organic pollutants included in the Stockholm Convention, their major health effects and their current regulatory status [7-23, 24•].

Many of these effects are related to how persistent organic pollutants interact with the environment. POPs are organic compounds that remain in the environment for extended periods of time. Once in the environment, they degrade very 
Table 1 Chemicals included in the Stockholm Convention - "The dirty dozen" and those subsequently added

\begin{tabular}{|c|c|c|c|c|}
\hline $\begin{array}{l}\text { Year Introduced to } \\
\text { Stockholm Convention }\end{array}$ & Chemical Name & Original Use & Main Health Effects* & Regulation Status in the USA ${ }^{\circ}$ \\
\hline \multirow[t]{5}{*}{2004} & $\begin{array}{l}\text { Aldrin } \\
\text { Dieldrin }\end{array}$ & $\begin{array}{l}\text { Insecticide } \\
\text { Insecticide }\end{array}$ & $\begin{array}{l}\text {-Seizures } \\
\text {-Anemia }\end{array}$ & $\begin{array}{l}\text { 1970: Production cancelled by } \\
\text { US Department of } \\
\text { Agriculture. } \\
\text { 1972: Re-approved by EPA in } \\
\text { 1972 to kill termites. } \\
\text { 1987: Production voluntarily } \\
\text { stopped by manufacturer. }\end{array}$ \\
\hline & Chlordane & Pesticide & $\begin{array}{l}\text {-Seizures } \\
\text {-Bronchitis, sinusitis } \\
\text {-Vomiting, diarrhea } \\
\text {-Anemia } \\
\text {-Immune dysfunction }\end{array}$ & $\begin{array}{l}\text { 1978: Cancelled by EPA for } \\
\text { agricultural use over next } \\
5 \text { years. } \\
\text { 1988: Cancelled for termite } \\
\text { control. }\end{array}$ \\
\hline & DDT & Pesticide & $\begin{array}{l}\text {-Seizures } \\
\text {-Premature labor } \\
\text {-Endocrine disruption } \\
\text {-Cancer }\end{array}$ & 1972: Cancelled by EPA \\
\hline & Endrin & Pesticide & $\begin{array}{l}\text {-Seizures, degenerative } \\
\text { neurological disease } \\
\text {-Vomiting, diarrhea } \\
\text {-Birth defects }\end{array}$ & 1986: Cancelled \\
\hline & Heptachlor & Pesticide & $\begin{array}{l}\text {-Reproductive toxicity } \\
\text {-Liver dysfunction }\end{array}$ & $\begin{array}{l}\text { 1988: Cancelled for use as } \\
\text { pesticide in home and on } \\
\text { crops } \\
\text { Currently used for fire ant } \\
\text { control in power } \\
\text { transformers. }\end{array}$ \\
\hline
\end{tabular}

Mirex

Toxaphene

PCBs

Hexachlorobenzene

Dibenzodioxins

Dibenzofurans

2009
Chlordecone

Lindane (gamma hexachlorocyclohexane)

Hexabromobiphenyl

Commercial pentaBDE Commercial octaBDE
Pesticide; fire retardant

Pesticide

Fungicide; additive to fireworks, ammunition \& synthetic rubber

Byproduct of chlorine bleaching by paper mill; combustion; herbicide (Agent Orange) Insecticide

Insecticide; use to treat lice \& $\&$ scabies in humans

Flame retardant

Flame retardant
-Kidney dysfunction -Liver dysfunction -Reproductive toxicity -Seizures -Immunodeficiency -Liver dysfunction -Renal failure -Thyroid cancer

Insulating fluid; paint additive; -Skin conditions -Depression -Anemia -Endocrine disruption -Liver Cancer

-Reproductive toxicity -Birth defects

-Liver dysfunction

-Chloracne

-Cancer

-Reproductive toxicity

-Type II diabetes

-Kidney dysfunction

-Liver dysfunction

-Reproductive toxicity

-Seizures

-Anemia

-Endocrine disruption

-Skin conditions -Immunodeficiency

-Liver dysfunction

-Renal failure

-Birth defects

-Endocrine disruption -Reproductive toxicity
1977-1978: Cancelled by EPA

1990: Cancelled by EPA

1977: Cancelled by EPA

1965: Cancelled by EPA

Still produced as byproduct of combustion; emissions regulated by EPA

1978: Cancelled by EPA

1976: Production stopped in USA

Currently still imported for insecticide use.

1976: Cancelled by EPA

2004: Voluntarily phased out of production 
Table 1 (continued)

\begin{tabular}{|c|c|c|c|c|}
\hline $\begin{array}{l}\text { Year Introduced to } \\
\text { Stockholm Convention }\end{array}$ & Chemical Name & Original Use & Main Health Effects* & Regulation Status in the USA ${ }^{\circ}$ \\
\hline & $\begin{array}{l}\text { Perfluorooctane sulfonic acid } \\
\text { (PFOS) and its salts } \\
\text { Perfluorooctane sulfonyl } \\
\text { fluoride (PFOS-F) }\end{array}$ & $\begin{array}{l}\text { Non-stick coating; protective } \\
\text { coating on carpet and } \\
\text { clothing }\end{array}$ & $\begin{array}{l}\text {-Neurotoxicity } \\
\text {-Endocrine disruption } \\
\text {-Cancer } \\
\text {-Immunodeficiency }\end{array}$ & $\begin{array}{l}\text { Currently undergoing } \\
\text { voluntary phase out: } 3 \mathrm{M} \\
\text { ceased production in } 2002 \text {. } \\
\text { Some production still exists } \\
\text { from other companies. }\end{array}$ \\
\hline & $\begin{array}{l}\text { Alpha and beta } \\
\text { hexachlorocyclohexane }\end{array}$ & Insecticide & $\begin{array}{l}\text {-Seizures } \\
\text {-Anemia } \\
\text {-Endocrine disruption } \\
\text {-Cancer }\end{array}$ & $\begin{array}{l}\text { 1976: Production stopped in } \\
\text { USA }\end{array}$ \\
\hline & Pentachlorobenzene & Pesticide byproduct & $\begin{array}{l}\text {-Reproductive toxicity } \\
\text {-Birth defects } \\
\text {-Liver dysfunction }\end{array}$ & $\begin{array}{l}\text { Produced as byproduct to } \\
\text { benzene and carbon } \\
\text { tetrachloride; not currently } \\
\text { regulated in the USA but } \\
\text { banned by the European } \\
\text { Union since } 2002 \text {. }\end{array}$ \\
\hline 2011 & Endosulfan & Pesticide & $\begin{array}{l}\text {-Seizures } \\
\text {-Hyperactivity }\end{array}$ & $\begin{array}{l}\text { Currently restricted to crops; } \\
\text { scheduled to be cancelled } \\
\text { for all uses in } 2016 \text {. }\end{array}$ \\
\hline 2013 & Hexabromocyclododecane & Flame retardant & $\begin{array}{l}\text {-Endocrine disruptor } \\
\text {-Cancer } \\
\text {-Neurotoxicity }\end{array}$ & Still produced in the USA. \\
\hline
\end{tabular}

*More information on the health effects of the chemicals included in the Stockholm Convention can be found in the following references [7-23, 24•]

${ }^{\circ}$ More information on the regulation status of the chemicals included in the Stockholm Convention can be found in the following references [7-23, 24•]

slowly in air, water, and soil, contributed to by the fact that they are highly halogenated [25•]. Because they do not easily break down, they remain present in the environment despite the fact that many are currently regulated and have not been in production for decades. Classically they bioaccumulate and biomagnify as they move up the food chain [26]. Consumers higher on the food chain such as humans and other carnivores are exposed to higher concentrations than those at the bottom, which only eat vegetation. Human exposure begins prenatally as many POPs can cross the placenta. After birth exposure occurs through breast milk $[27,28]$ and also through inhalation, ingestion, and skin contact [28].

Once in the body, POPs preferentially partition in tissues with high lipid content such as adipose tissue and the liver, due to their lipophilic nature via uptake by adipocytes, and are then stored within lipid droplets. However, in the long term, this accumulation can lead to larger body burdens, which are then slowly released into the blood stream. When there is large mobilization of adipose tissue, such as during periods of weight loss, pregnancy, after pregnancy and during breastfeeding, the POPs may be released at a faster rate from adipose tissue into the blood stream [29]. Several studies have shown that after large weight losses, like after bariatric surgery, there are higher serum levels of POPs $[30 \bullet, 31]$.
Some of POPs health effects are likely mediated by their interaction with the adipose and other tissues in which they are stored. POPs may induce obesogenic effects and also induce a pro-inflammatory state that can lead to the metabolic syndrome and diabetes $[29,32,33]$. These effects may also be age/period of development specific [34]. There have been recent studies that hypothesize exposure to persistent organic pollutants with the increasing prevalence of cardiovascular disease (CVD) [32, 35-37]; little evidence can link POPs with increasing incidence of cardiovascular disease and the metabolic syndrome given a dearth of prospective studies [38]. The lipophilic nature of the persistent organic pollutants may induce CVD by making lipophilic membranes more permeable to toxic hydrophilic chemicals [32], which in turn results in an inflammatory response. The exposure of lipophilic and hydrophilic compounds at the same time or sequentially may be more toxic than individually [32].

This article reviews some of the persistent organic pollutants that exist in significant concentrations in the environment such that the general population may have significant exposure. The review covers dioxins, polychlorinated biphenyl ethers, polybrominated diphenyl ethers, and hexabromocyclododecane. See Fig. 1 for the chemical structures of each pollutant covered. The review includes bisphenol A which, while not itself a persistent 
Fig. 1 Chemical structure of selected persistent organic pollutants. DDT, dioxin, PCB, PBDE, BPA, and HBCD

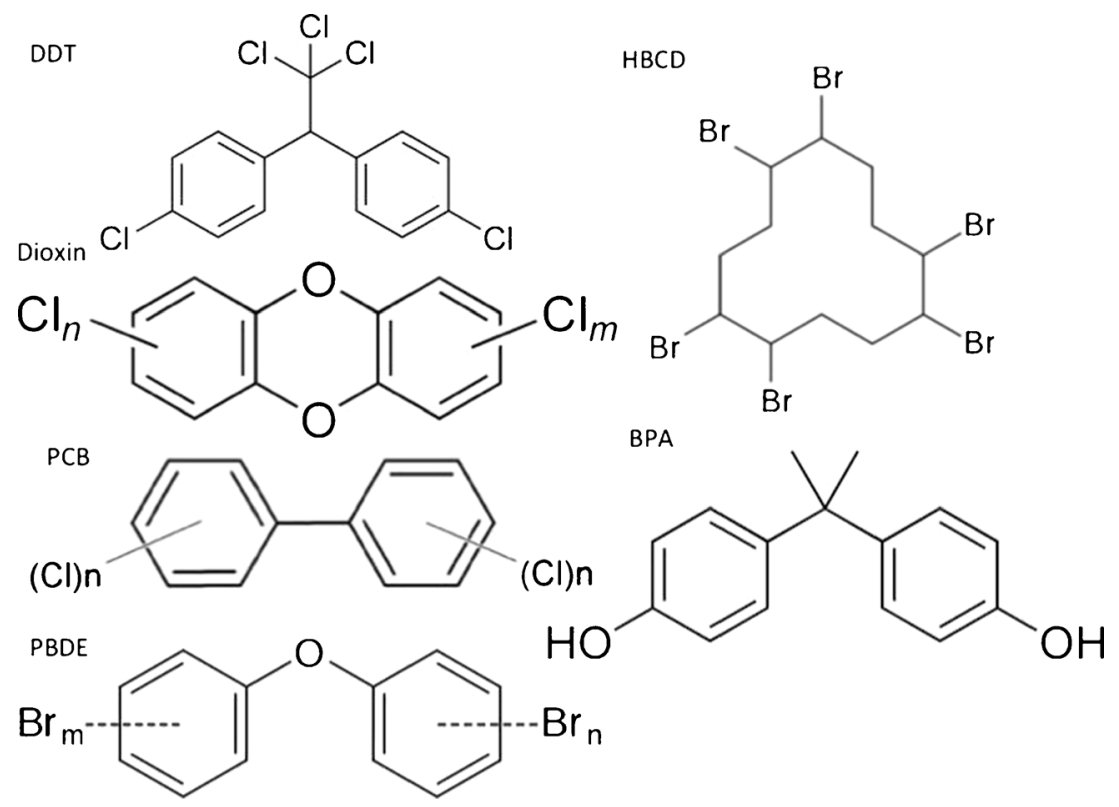

organic pollutant, does act like a POP and is often grouped with POPs when environmental pollutants are discussed.

\section{Dioxins and Polychlorinated Biphenyl Ethers (PCBs)}

Dioxin is also a well-known persistent organic pollutant secondary to its use in Agent Orange during the Vietnam War. Agent Orange itself refers to all herbicides that were used during the Vietnam War, but its legacy refers to its contamination with 2, 3, 7, 8-tetrachlor-dibenzo-para-dioxin (TCDD) [39]. Dioxin itself is a generic term that refers to a group of 210 different compounds, 75 polychlorinated dibenzo-pdioxins (PCDDs) and 135 polychlorinated dibenzofurans (PCDFs) [25•]. Their toxicity varies dependent on the position of chlorine within the congener. Dioxin itself is not produced intentionally except for research purposes, but rather is a byproduct from incineration or secondary to the processing of other chemicals, including herbicides. Polychlorinated biphenyls, some of which act similarly to dioxins, were on the other hand, intentionally created for their heat resistant and insulating properties. PCBs were frequently used as heat exchange fluids in industrial processes and in paints and ceiling tiles. PCB production was banned in the USA by the EPA in 1979. Because of their persistence, PCBs are still seen in measurable levels/levels high enough to affect health today, though these levels have declined at a slow rate since their ban. Current exposure to dioxins and other dioxin-like compounds through eating contaminated foodstuffs is thought to constitute $90 \%$ of exposure [40, 41]; dairy and animal products more so than produce [42], although inhalation and ingestion of dust also contribute [43, 44].
Initially proposed by the Canadian Ministry of the Environment and then later adopted by the US Environmental Protection Agency (EPA) and the World Health Organization (WHO), dioxins and dioxin-like compounds are measured in terms of Toxic Equivalency Factors (TEFs) [45]. TEFs are important given the varying toxicities of the many different dioxin-like compounds, which include certain PCBs. Because they are usually not found in pure form but instead in mixtures, the individual TEFs are summed to form the Total Toxicity Equivalence of the substance [45], which expresses the mixtures' toxicity as if it were pure TCDD [46]. Over the years, these TEFs are updated according to new research and added to for new compounds that are found to have dioxinlike activity [47, 48]. The TEF assignment is based on the biological activity of each compound with the aryl hydrocarbon receptor (AhR), also known as the dioxin receptor. However, not all compounds that bind the Ah-receptor are considered dioxin-like. Compounds that are considered dioxin-like and are given TEFs, must meet the following 4 criteria

- Be structurally similar to TCDD,

- Bind to the aryl-hydrocarbon receptor,

- Produce a response on binding to the Ah-R,

- Be persistent and bioaccumulate and biomagnify up the food chain [47].

When dioxin-like compounds bind the Ah-receptor, the receptor translocates to the nucleus, eventually regulating gene expression through binding with the dioxin response elements. This mechanism controls many reactions necessary for human life, such as drug metabolizing phase I, II, and III genes, including CYP1A1, glutathione S-transferases, and aldehyde dehydrogenase. It also regulates aspects of human 
growth and development, and may act as a tumor suppressor [25•]. Most frequently reported human cancers associated with dioxin and dioxin-like compounds include lung cancer, hepatocellular carcinoma, non-Hodgkin's lymphoma, and malignant melanoma [10].

\section{Polybrominated Diphenyl Ethers (PBDEs) and Hexabromocyclododecane (HBCD)}

Brominated flame-retardants, including PBDEs and HBCD, have been widely used as flame-retardants in carpeting, furniture cushions, and electrical appliances since the 1970s when the adverse health effects of PCBs were discovered. The bromines, as the chloride atoms did for PCBs, are capable of quenching free radical production from fires, and thus preventing further fire spread [49•]. There are 209 theoretical PBDE congeners based on the positions of the bromines around the diphenyl ether rings. There are three main commercial products named for the number of bromines present on the most prevalent congener in the mixture: pentaBDE, octaBDE, and decaBDE. Certain PBDEs were initially phased out in the USA in 2004 with penta and octaBDE preparations. Commercial production of decaBDE mixtures was stopped in the USA by the end of 2013.

The general population is exposed through ingestion of foods; PBDEs having bioaccumulated in animals higher on the food chain [50], or in produce exposed to pesticides. In recent years, ingestion and inhalation of dust has become an increasing source of exposure, either on par or surpassing exposure through foodstuffs [51-53]. There has been some evidence to suggest that PBDE sera concentrations are slowly decreasing over time, but this trend has not been shown to be statistically significant in a recent paper using National Health and Nutrition Examination Survey (NHANES). As more time passes from when commercial penta- and octa-BDE congeners were phased out in 2004, concentrations will likely slowly decrease. Unlike with the lower brominated congeners, the more recent phase out of deca-BDE, and it's main component, BDE-209 is thought to have less of an impact on serum levels given its shorter half-life of weeks rather than years [54•]. Additionally BDE-209 exposure at baseline is already lower, with detection in $12 \%$ of samples from NHANES 2005-2006 and 11\% in 2007-2008 [54•].

The major health effects in humans are divided into three main categories: endocrine disruption, reproductive and developmental toxicity, and neurotoxicity [25•]. In terms of endocrine disruption, alterations in thyroid function are prominent. Studies have shown that this is likely due to the similarities in structure between PBDEs and the thyroid hormones T3 and T4. Most animal studies show that increasing PBDE concentrations lead to decreased free and/or total T4 in a dose dependent fashion [55-57]. Certain human studies on the other hand note that higher PBDE levels are associated with higher levels of T4 and decreased TSH concentrations [57-60]. It is not entirely clear if PBDEs' effect on reproductive function is mediated by their effect on thyroid function or independently. It is well known that thyroid hormones can influence ovulation, menstruation, and ultimately fertility. Within animal studies, PBDEs can have both pro-estrogen and anti-estrogen effects [61, 62]. PBDEs have also been associated with delayed onset of puberty. Elevated PBDE concentrations have been associated with increased time to pregnancy [63]. This has significant impact given widespread exposure to certain PBDE congeners in the USA [54 ${ }^{\bullet}$ and the high cost of fertility treatments that parents and society may have to pay to have children.

Higher concentrations of PBDE levels in maternal serum have been correlated with lower scores in offspring's intelligence and attention $[64,65]$. One potential hypothesis is related to the role that maternal thyroid hormones have in fetal brain development [66]. Mice studies demonstrate that the neurotoxicity may occur in a dose dependent fashion [49*, 67-69]. Exposure can lead to alterations in mice locomotion, rearing, and total activity levels [67]. These neurobehavioral affects appear to be most prominent when exposure occurs within early neurodevelopment in mice, within the first two weeks post-natally [70]; this time period corresponds to the last trimester and early childhood in humans [49॰]. The neurotoxicity may not be limited to behavioral effects but also expands to synaptic plasticity; elevated levels of BDE-209 in the hippocampus corresponding to decreased plasticity in rats [49॰].

Hexabromocyclododecane (HBCD), while a brominated flame retardant like PBDEs, is actually composed of a nonaromatic, brominated cyclic alkane. Sixteen potential stereoisomers exist with commercial mixtures largely comprised of $\gamma$-diastereomers with smaller amounts of $\alpha$ - and $\beta$ diastereomers [25•]. However when exposed to high temperatures, as can occur during processing or production, the stereoisomers rearrange into a specific composition on $78 \%$ $\alpha, 13 \% \beta$, and $9 \% \gamma$-HBCD [71]. Like PBDEs, it is also lipophilic, and both biomagnifies and bioaccumulates within the environment. HBCD enters the environment during production or by leaching out of commercial products. It then binds tightly to soil and sewage particulates given their strongly hydrophobic character [71]. Because HBCD biomagnifies, it is found in increasing levels in fish, birds, and humans, both within blood and breast milk [71]. It is unknown if the major exposure to humans is from the diet or from dust exposure as is becoming the case for PBDEs [72]. Compared to PBDEs, research into HBCD is limited. HBCDs are known to induce drug-metabolizing enzymes in rats, induce cancer, and disrupt thyroid homeostasis [71, 73]. Rats with neonatal exposures also have developmental neurotoxic effects such as alterations in learning and memory [71]. 


\section{Bisphenol A (BPA)}

Bisphenol A was first synthesized in 1891, and has since become one of the most commonly produced chemicals worldwide [74]. While not technically a persistent organic pollutant because of its short half-life, BPA is often grouped together with other POPs given its ubiquitous presence in the environment. Despite BPA's short half-life, it is found in urine at relatively constant levels like a chemical with much longer half-life would. It is also found in blood, breast milk, saliva and amniotic fluid [74]. The concentrations in amniotic fluid are up to five times higher than those in corresponding maternal serum, demonstrating a significant prenatal exposure [75]. Within the environment, BPA is present in soil, dust, water, and air samples.

Bisphenol A is currently used as an additive in polycarbonate plastics and epoxy resins in the lining of metal food cans, in paints, office equipment, and dental adhesives to name a few [74]. BPA is also used in carbonless thermal receipt paper as a color developer. Food, especially through canned items, is thought to be the predominant source of exposure [76]; BPA monomers can migrate out of polycarbonate linings in cans into the food products they house during storage or during processing [77]. In younger children with more hand to mouth contact, dust may be a significant pathway to exposure $[78,79]$. In adults, BPA quickly undergoes first-pass metabolism in the liver, and sometimes gut, to BPA-glucuronide, which is then renally excreted [80]. However, in infants, liver enzyme activity is lower, leading to decreased glucuronidation of BPA in infants and potentially greater exposure in an already at-risk population.

Thermal receipt paper may also be a significant means of exposure given the paper's ubiquitous presence in twenty-first century life; this exposure may be due to unwashed hand to mouth behavior or through direct dermal contact. It has even been reported that cashiers have higher urinary levels of BPA than the general public [81].

The toxicity of bisphenol A stems from its nature as an endocrine disruptor. Endocrine disruptors as defined by the WHO are "exogenous substance of mixture that alters the function of the endocrine system and consequently causes adverse effects in an intact organism, or its progeny or its subpopulation" [82]. As an endocrine disruptor, BPA interacts with both nuclear estrogen receptors and estrogen receptors on the cell membrane; at higher doses, BPA can also interact with androgen and thyroid hormone receptors [83]. Given that the endocrine system is highly regulated and hormones vary widely with age and stage of development, it is understandable that human sensitivity to BPA varies widely with age and maturity, leading to susceptible developmental windows. This complicates the study of BPA with regards to when the exposure occurs and the latency period to the many different health effects associated with BPA, ranging from infertility to cardiovascular disease to impairments in neurodevelopmental outcomes. Though the evidence is mixed, early exposure has been associated with neurodevelopmental, specifically autism spectrum disorders and attention deficit hyperactivity disorder [84]. When pregnant mice were exposed to BPA, there was increased insulin resistance during pregnancy with corresponding decreased glucose tolerance. These mice also had higher levels of insulin resistance post-partum than their controls; their offspring also had increased insulin resistance [85]. These findings correlate with human epidemiology studies that demonstrate an association between BPA exposure and type 2 diabetes and heart disease [86]. Adult exposure of BPA to rats showed an increase in hematological malignancies, testicular interstitial cell tumors in male rats, and an increase in fibroadenomas in female rats [87].

\section{Conclusions}

Persistent organic pollutants constitute a significant environmental exposure and despite increasing regulations at the national and global level, the general population continues to be exposed at levels that may cause lasting health effects. Dioxins and PCBs have been well studied but the newer persistent organic pollutants like PBDEs and perfluorinated compounds, not explored here, require more research to further elucidate their health effects, especially given that much of what is known of POPs health effects is extrapolated from animal studies. Additionally, many of the human studies are occupational assessments where exposures are at much higher levels than those of the general population, and are retrospective or cross-sectional in nature. Even less is known about the exposure to vulnerable populations like infants, children, and pregnant women. As stewards of their patients' health, it behooves clinicians to become familiar with the different environmental exposures their patients may face.

Acknowledgments Arnold Schecter has received grant support from National Children's Program (NCP)/NIH 2 contracts; NCI/NIH 1 contract. He received NIH funds to travel to Vietnam for NCI research and to present findings at one scientific meeting; and he received NIH funds to travel to NIH for NCP meetings.

\section{Compliance with Ethics Guidelines}

Conflict of Interest Darrah Haffner declares that she has no conflict of interest.

Arnold Schecter has received consulting from the US EPA as he attended and participated in Dioxin Expert Panel Reviews; he also received consulting fees for several legal cases and gave expert testimony in legal cases relating to dioxins. He received royalties for editorial work on Maxcy Rosenau Last Public Health and Preventive Medicine, 14 and 15 editions. He also received royalties for editorial work on Dioxins and Health, 2nd and 3rd editions, from John Wiley and Sons. 
Human and Animal Rights and Informed Consent This article does not contain any studies with human or animal subjects performed by any of the authors.

\section{References}

Papers of particular interest, published recently, have been highlighted as:

- Of importance

1. Carson R. Silent spring. Boston: Houghton Mifflin; 1962.

2. Sheer RaM, Doug. How important was Rachel Carson's Silent Spring in the recovery of bald eagles and other bird species? Scientific American, 2012.

3. Kuratsune $\mathrm{M}$ et al. Epidemiologic study on Yusho, a poisoning caused by ingestion of rice oil contaminated with a commercial brand of polychlorinated biphenyls. Environ Health Perspect. 1972;1:119-28.

4. Ryan JJ. In: Schecter A, editor. The Yushchenko dioxin poisoning: chronology and pharmacokinetics, in dioxins and health: including other persistent organic pollutants and endocrine disruptors. NJ: John Wiley and Sons; 2012.

5. Sorg $\mathrm{O}$ et al. 2, 3, 7, 8-tetrachlorodibenzo-p-dioxin (TCDD) poisoning in Victor Yushchenko: identification and measurement of TCDD metabolites. Lancet. 2009;374(9696):1179-85.

6. Program SCotUNE. The 12 initial POPs under the Stockholm Convention. 2008 [cited 2013 December 28, 2013]. Available from: http://chm.pops.int/TheConvention/ThePOPs/ The12InitialPOPs/tabid/296/Default.aspx.

7. Registry AfTSaD. Toxicological profile for Aldrin/Dieldrin. September 2002 March 3, 2011 February 14, 2014]. Available from: http://www.atsdr.cdc.gov/ToxProfiles/TP.asp?id=317\&tid= 56-bookmark07.

8. Registry AfTSaD. Toxicological profile for Chlordane. 1994 March 3, 2011 February 14, 2014]. Available from: http://www.atsdr.cdc. gov/ToxProfiles/TP.asp?id=355\&tid $=62$.

9. Registry AfTSaD. Toxicological profile for DDT, DDE, and DDD. 2002 March 3, 2011 February 14, 2014]. Available from: http:// www.atsdr.cdc.gov/toxprofiles/tp.asp?id=81\&tid=20.

10. Registry AfTSaD. Toxicological profile for Chlorinated dibenzo-pdioxins (CDDs). 1988 March 3, 2011 February 14, 2014]. Available from: http://www.atsdr.cdc.gov/ToxProfiles/TP.asp?id=366\&tid= 63.

11. Registry AfTSaD. Toxicological profile for Endrin. 1996 March 3, 2011 February 14, 2014]. Available from: http://www.atsdr.cdc. gov/toxprofiles/tp.asp?id=617\&tid=114.

12. Registry AfTSaD. Toxicological profile for Heptachlor and Heptachlor epoxide. 2007 March 3, 2011 February 15, 2014]. Available from: http://www.atsdr.cdc.gov/toxprofiles/tp.asp?id= 746\&tid $=135$.

13. Registry AfTSaD. Toxicological profile for Mirex and Chlordecone. 1995 March 3, 2011 February 15, 2014]. Available from: http://www.atsdr.cdc.gov/ToxProfiles/TP.asp?id=643\&tid= 118.

14. Registry AfTSaD. Toxicological profile for Toxaphene. 2010 March 3, 2011 February 15, 2014]. Available from: http://www. atsdr.cdc. gov/toxprofiles/tp.asp?id $=548 \&$ tid $=99$.

15. Registry AfTSaD. Toxicological profile for Polychlorinated biphenyls (PCBs). 2000 March 3, 2011 February 15, 2014]. Available from: http://www.atsdr.cdc.gov/ToxProfiles/TP.asp?id=142\&tid= 26.
16. Registry AfTSaD. Toxicological profile for Hexachlorobenzene. 2013 March 3, 2011 February 15, 2014]. Available from: http:// www.atsdr.cdc.gov/toxprofiles/tp.asp?id=627\&tid=115.

17. Registry AfTSaD. Toxicological profile for Hexachlorocyclohexane. 2005 March 13, 2011 February 15, 2014]. Available from: http:// www.atsdr.cdc.gov/toxfaqs/tf.asp?id $=753 \&$ tid $=138$.

18. Registry AfTSaD. Toxicological profile for Polybromintaed biphenyls and Polybrominated diphenyl ethers (PBBs and PBDEs). 2004 February 15, 2014]. Available from: http://www.atsdr.cdc.gov/ ToxProfiles/TP.asp?id $=529 \&$ tid $=94$.

19. Agency EP. Draft risk assessment of the potential human health effects associated with exposure to Perflouroctanoic acids and its salts. 2005 February 15, 2014]. Available from: http://www.atsdr. cdc.gov/ToxProfiles/tp200-c6.pdf.

20. Steenland K, Fletcher T, Savitz DA. Epidemiologic evidence on the health effects of perfluorooctanoic acid (PFOA). Environ Health Perspect. 2010;118(8):1100-8.

21. Registry AfTSaD. Toxicological profile for Endosulfan. 2013 March 3, 2011 February 15, 2014]. Available from: http://www. atsdr.cdc.gov/toxprofiles/tp.asp?id=609\&tid=113.

22. Program SCotUNE. The new POPs under the Stockholm Convention. 2009 [cited 2014 February 14, 2014]. Available from: http://chm.pops.int/TheConvention/ThePOPs/TheNewPOPs/tabid/ 2511/Default.aspx.

23. Program SCotUNE. SC-5/3: Listing of technical endosulfan and its related isomers. Switzerland: United Nations Environmental Program; 2011.

24. Program SCotUNE. Listing of hexabromocyclododecane 2013, United Nations Environmental Program: Switzerland. Report from the most recent Stockholm Convention, May 2013

25. Wikoff D, Fitzgerald L, Birnbaum L. Persistent organic pollutants: An overview, in Dioxins and Health: Including other persistent organic pollutants and endocrine disruptors. In: Schecter A, editor. The introduction to the book Dioxins and Health by Arnold Schecter, which is an in depth overview of current research on persistent organic pollutants. NJ: John Wiley \& Sons; 2012.

26. Mrema EJ et al. Persistent organochlorinated pesticides and mechanisms of their toxicity. Toxicology. 2013;307:74-88.

27. Perera FP et al. A summary of recent findings on birth outcomes and developmental effects of prenatal ETS, PAH, and pesticide exposures. Neurotoxicology. 2005;26(4):573-87.

28. Schecter A et al. Polybrominated diphenyl ethers (PBDEs) in U.S. mothers' milk. Environ Health Perspect. 2003;111(14):1723-9.

29. La Merrill $\mathrm{M}$ et al. Toxicological function of adipose tissue: focus on persistent organic pollutants. Environ Health Perspect. 2013;121(2):162-9.

30. Kim MJ et al. Inflammatory pathway genes belong to major targets of persistent organic pollutants in adipose cells. Environ Health Perspect. 2012;120(4):508-14. Primary research investigating the link between dioxin and $P C B$ exposure and inflammation, mediated by the aryl hydrocarbon receptor in adipose tissue.

31. Lim JS et al. Inverse associations between long-term weight change and serum concentrations of persistent organic pollutants. Int $\mathrm{J}$ Obes (Lond). 2011;35(5):744-7.

32. Zeliger HI. Lipophilic chemical exposure as a cause of cardiovascular disease. Interdiscip Toxicol. 2013;6(2):55-62.

33. Taylor $\mathrm{KW}$ et al. Evaluation of the association between persistent organic pollutants (POPs) and diabetes in epidemiological studies: a national toxicology program workshop review. Environ Health Perspect. 2013;121(7):774-83.

34. Tang-Peronard JL et al. Endocrine-disrupting chemicals and obesity development in humans: a review. Obes Rev. 2011;12(8):622-36.

35. Zeliger HI. Lipophilic chemical exposure as a cause of type 2 diabetes (T2D). Rev Environ Health. 2013;28(1):9-20. 
36. Lind PM et al. Circulating levels of persistent organic pollutants (POPs) and carotid atherosclerosis in the elderly. Environ Health Perspect. 2012;120(1):38-43.

37. Lee DH et al. Relationship between serum concentrations of persistent organic pollutants and the prevalence of metabolic syndrome among non-diabetic adults: results from the national health and nutrition examination survey 1999-2002. Diabetologia. 2007;50(9):1841-51.

38. Lind L, Lind PM. Can persistent organic pollutants and plasticassociated chemicals cause cardiovascular disease? J Intern Med. 2012;271(6):537-53.

39. Hammond SaS, Arnold. Agent Orange: health and environmental issues in Vietnam, Cambodia, and Laos. In: A. Schecter, editor. Dioxins and Health: Including other persistent organic pollutants and endocrine disruptors. NJ: John Wiley and Sons; 2012.

40. Kvalem HE et al. Development and validation of prediction models for blood concentrations of dioxins and PCBs using dietary intakes. Environ Int. 2012;50:15-21.

41. Liem AK, Furst P, Rappe C. Exposure of populations to dioxins and related compounds. Food Addit Contam. 2000;17(4):241-59.

42. Vogt $\mathrm{R}$ et al. Cancer and non-cancer health effects from food contaminant exposures for children and adults in California: a risk assessment. Environ Health. 2012;11:83.

43. Wang $\mathrm{W}$ et al. Exposure assessment and distribution of polychlorinated biphenyls (PCBs) contained in indoor and outdoor dusts and the impacts of particle size and bioaccessibility. Sci Total Environ. 2013;463-464:1201-9.

44. Kerger BD et al. An adaptable internal dose model for risk assessment of dietary and soil dioxin exposures in young children. Toxicol Sci. 2007;100(1):224-37.

45. DeVito M. Toxicity equivalence factors for Dioxin and related compounds, in Dioxins and Health: Including other persistent organic pollutants and endocrine disruptors, A. Schecter, Editor. 2012, John Wiley and Sons: NJ.

46. Schecter A et al. Dioxins: an overview. Environ Res. 2006;101(3): 419-28.

47. Van den Berg M et al. The 2005 World Health Organization reevaluation of human and mammalian toxic equivalency factors for dioxins and dioxin-like compounds. Toxicol Sci. 2006;93(2): $223-41$.

48. van den Berg M et al. Polybrominated dibenzo-p-dioxins, dibenzofurans, and biphenyls: inclusion in the toxicity equivalency factor concept for dioxin-like compounds. Toxicol Sci. 2013;133(2):197208.

49. Dingemans MM, Van den Berg M, Westerink RH. Neurotoxicity of brominated flame retardants: (in)direct effects of parent and hydroxylated polybrominated diphenyl ethers on the (developing) nervous system. Environ Health Perspect. 2011;119(7):900-7. Overview of the effect of PBDEs and hydroxylated PBDEs on neural development, and the interaction between PBDEs and other environmental contaminants on neurotoxicity.

50. Schecter A et al. Polybrominated diphenyl ethers (PBDEs) and hexabromocyclodecane (HBCD) in composite U.S. food samples. Environ Health Perspect. 2010;118(3):357-62.

51. Lee S, Kannan K, Moon HB. Assessment of exposure to polybrominated diphenyl ethers (PBDEs) via seafood consumption and dust ingestion in Korea. Sci Total Environ. 2013;443:24-30.

52. Lorber M. Exposure of Americans to polybrominated diphenyl ethers. J Expo Sci Environ Epidemiol. 2008;18(1):2-19.

53. Dirtu AC, Covaci A. Estimation of daily intake of organohalogenated contaminants from food consumption and indoor dust ingestion in Romania. Environ Sci Technol. 2010;44(16):6297-304.

54. Sjodin A et al. Polybrominated diphenyl ethers, polychlorinated biphenyls, and persistent pesticides in serum from the national health and nutrition examination survey: 2003-2008. Environ Sci Technol. 2014;48(1):753-60. An account of American exposure to persistent organic pollutants from the National Health and Nutrition Examination Survey.

55. Hallgren S, Darnerud PO. Polybrominated diphenyl ethers (PBDEs), polychlorinated biphenyls (PCBs) and chlorinated paraffins (CPs) in rats-testing interactions and mechanisms for thyroid hormone effects. Toxicology. 2002;177(2-3):227-43.

56. Hallgren $\mathrm{S}$ et al. Effects of polybrominated diphenyl ethers (PBDEs) and polychlorinated biphenyls (PCBs) on thyroid hormone and vitamin A levels in rats and mice. Arch Toxicol. 2001;75(4):200-8.

57. Chevrier $\mathrm{J}$ et al. Polybrominated diphenyl ether (PBDE) flame retardants and thyroid hormone during pregnancy. Environ Health Perspect. 2010;118(10):1444-9.

58. Bloom $\mathrm{M}$ et al. Environmental exposure to PBDEs and thyroid function among New York anglers. Environ Toxicol Pharmacol. 2008;25(3):386-92.

59. Dallaire $\mathrm{R}$ et al. Thyroid function and plasma concentrations of polyhalogenated compounds in Inuit adults. Environ Health Perspect. 2009;117(9):1380-6.

60. Dallaire R et al. Thyroid hormone levels of pregnant inuit women and their infants exposed to environmental contaminants. Environ Health Perspect. 2009;117(6):1014-20.

61. Lilienthal $\mathrm{H}$ et al. Effects of developmental exposure to 2,2,4,4,5pentabromodiphenyl ether (PBDE-99) on sex steroids, sexual development, and sexually dimorphic behavior in rats. Environ Health Perspect. 2006;114(2):194-201.

62. Stoker TE et al. Assessment of DE-71, a commercial polybrominated diphenyl ether (PBDE) mixture, in the EDSP male and female pubertal protocols. Toxicol Sci. 2004;78(1):144-55.

63. Harley KG et al. PBDE concentrations in women's serum and fecundability. Environ Health Perspect. 2010;118(5):699-704.

64. Herbstman JB et al. Prenatal exposure to PBDEs and neurodevelopment. Environ Health Perspect. 2010;118(5): $712-9$.

65. Roze E et al. Prenatal exposure to organohalogens, including brominated flame retardants, influences motor, cognitive, and behavioral performance at school age. Environ Health Perspect. 2009;117(12):1953-8.

66. Auso $\mathrm{E}$ et al. A moderate and transient deficiency of maternal thyroid function at the beginning of fetal neocorticogenesis alters neuronal migration. Endocrinology. 2004;145(9):4037-47.

67. Eriksson P, Jakobsson E, Fredriksson A. Brominated flame retardants: a novel class of developmental neurotoxicants in our environment? Environ Health Perspect. 2001;109(9):903-8.

68. Viberg $\mathrm{H}$ et al. Neurobehavioral derangements in adult mice receiving decabrominated diphenyl ether (PBDE 209) during a defined period of neonatal brain development. Toxicol Sci. 2003;76(1):112-20.

69. Viberg $\mathrm{H}$ et al. Neonatal exposure to higher brominated diphenyl ethers, hepta-, octa-, or nonabromodiphenyl ether, impairs spontaneous behavior and learning and memory functions of adult mice. Toxicol Sci. 2006;92(1):211-8.

70. Eriksson $\mathrm{P}$ et al. A brominated flame retardant, 2,2',4,4',5pentabromodiphenyl ether: uptake, retention, and induction of neurobehavioral alterations in mice during a critical phase of neonatal brain development. Toxicol Sci. 2002;67(1):98103.

71. Covaci A et al. Hexabromocyclododecanes (HBCDs) in the environment and humans: a review. Environ Sci Technol. 2006;40(12): 3679-88.

72. Schecter A et al. Hexabromocyclododecane (HBCD) stereoisomers in U.S. food from Dallas, Texas. Environ Health Perspect. 2012;120(9):1260-4.

73. Palace $\mathrm{V}$ et al. Altered thyroxine metabolism in rainbow trout (Oncorhynchus mykiss) exposed to hexabromocyclododecane (HBCD). Chemosphere. 2010;80(2):165-9. 
74. Schug T, Vogel S, Vandeberg L, Braun J, Hauser R, Taylor J, et al. Dioxins and Health: including other persistent organic pollutants and endocrine disruptors. In: Schecter A, editor. Dioxins and Health: including other persistent organic pollutants and endocrine disruptors. NJ: John Wiley and Sons; 2012.

75. Ikezuki $\mathrm{Y}$ et al. Determination of bisphenol A concentrations in human biological fluids reveals significant early prenatal exposure. Hum Reprod. 2002;17(11):2839-41.

76. Geens $\mathrm{T}$ et al. A review of dietary and non-dietary exposure to bisphenol-A. Food Chem Toxicol. 2012;50(10):3725-40.

77. Kang JH, Kondo F, Katayama Y. Human exposure to bisphenol A. Toxicology. 2006;226(2-3):79-89.

78. Calafat AM et al. Exposure of the U.S. population to bisphenol A and 4-tertiary-octylphenol: 2003-2004. Environ Health Perspect. 2008;116(1):39-44.

79. Loganathan SN, Kannan K. Occurrence of bisphenol A in indoor dust from two locations in the eastern United States and implications for human exposures. Arch Environ Contam Toxicol. 2011;61(1):68-73.

80. Nachman R, Hartle JC, Lees PSJ, Groopman JD. Early life metabolism of bisphenol A: a systematic review of the literature. Curr Envir Health Reports, 2014
81. Braun JM et al. Variability and predictors of urinary bisphenol A concentrations during pregnancy. Environ Health Perspect. 2011;119(1):131-7.

82. Safety IPoC. In: Damstra T, Barlow S, Bergman A, Kavlock R, Van der Kraak G, editors. Global Assessment of the State-of-theScience of Endocrine Disruptors. Switzerland: World Health Organization; 2002.

83. vom Saal FS et al. Chapel Hill bisphenol A expert panel consensus statement: integration of mechanisms, effects in animals and potential to impact human health at current levels of exposure. Reprod Toxicol. 2007;24(2):131-8.

84. de Cock M, Maas YG, van de Bor M. Does perinatal exposure to endocrine disruptors induce autism spectrum and attention deficit hyperactivity disorders? Rev Acta Paediatr. 2012;101(8):811-8.

85. Alonso-Magdalena $\mathrm{P}$ et al. Bisphenol A exposure during pregnancy disrupts glucose homeostasis in mothers and adult male offspring. Environ Health Perspect. 2010;118(9):1243-50.

86. Lang IA et al. Association of urinary bisphenol A concentration with medical disorders and laboratory abnormalities in adults. Jama. 2008;300(11):1303-10.

87. Keri RA et al. An evaluation of evidence for the carcinogenic activity of bisphenol A. Reprod Toxicol. 2007;24(2):240-52. 